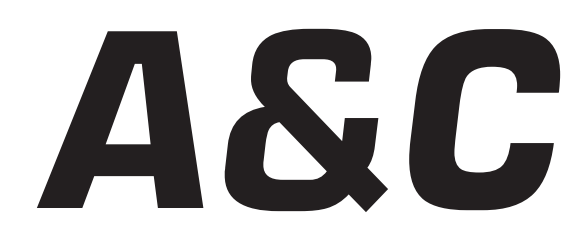

Revista de Direito Administrativo \& Constitucional

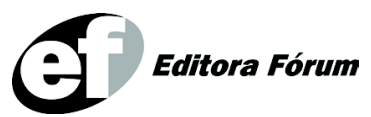

ISSN 1516-3210 


\section{A\&C REVISTA DE DIREITO ADMINISTRATIVO E CONSTITUCIONAL}

IPDA

Instituto Paranaense

de Direito Administrativo

Direção Geral

Romeu Felipe Bacellar Filho

Direção Editorial

Paulo Roberto Ferreira Motta

Direção Executiva

Emerson Gabardo

Conselho de Redação

Edgar Chiuratto Guimarães

Adriana da Costa Ricardo Schier

Célio Heitor Guimarães

\section{Conselho Editorial}

Adilson Abreu Dallari

Alice Gonzáles Borges

Carlos Ari Sundfeld

Carlos Ayres Britto

Carlos Delpiazzo

Cármen Lúcia Antunes Rocha

Celso Antônio Bandeira de Mello

Clèmerson Merlin Clève

Clóvis Beznos

Enrique Silva Cimma

Eros Roberto Grau

Fabrício Motta

Guilhermo Andrés Muñoz (in memoriam)

Jaime Rodríguez-Arana Muñoz

Jorge Luís Salomoni

José Carlos Abraão
José Eduardo Martins Cardoso
José Luís Said
José Mario Serrate Paz
Juan Pablo Cajarville Peruffo
Juarez Freitas
Julio Rodolfo Comadira
Luís Enrique Chase Plate
Lúcia Valle Figueiredo
Manoel de Oliveira Franco Sobrinho
(in memoriam)
Marçal Justen Filho
Marcelo Figueiredo
Márcio Cammarosano
Maria Cristina Cesar de Oliveira

Nelson Figueiredo

Odilon Borges Junior

Pascual Caiella

Paulo Eduardo Garrido Modesto

Paulo Henrique Blasi

Paulo Neves de Carvalho (in memoriam)

Paulo Ricardo Schier

Pedro Paulo de Almeida Dutra

Regina Maria Macedo Nery Ferrari

Rogério Gesta Leal

Rolando Pantoja Bauzá

Sérgio Ferraz

Valmir Pontes Filho

Yara Stropa

Weida Zancaner

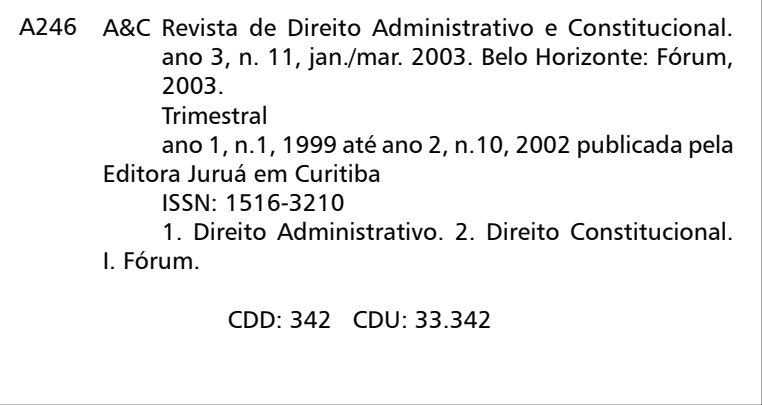

(C) Editora Fórum Ltda. 2007

Todos os direitos reservados. É proibida a reprodução total ou parcial, de qualquer forma ou por qualquer meio eletrônico ou mecânico, inclusive através de processos xerográficos, de fotocópias ou de gravação, sem permissão por escrito do possuidor dos direitos de cópias (Lei nº 9.610, de 19.02.1998).

Editora Fórum Ltda

Av. Afonso Pena, $2770-15 \% 16^{\circ}$ andar - Funcionários

CEP 30130-007 - Belo Horizonte/MG - Brasil

Tel.: 08007043737

Internet: www.editoraforum.com.br

e-mail: editoraforum@editoraforum.com.br
Editor responsável: Luís Cláudio Rodrigues Ferreira Projeto gráfico e diagramação: Luis Alberto Pimenta Revisora: Olga M. A. Sousa

Pesquisa jurídica: Fátima Ribeiro - OAB/MG 74868

Bibliotecária: Leila Aparecida Anastácio

CRB 2809/MG 6ª região

Os conceitos e opiniões expressas nos trabalhos assinados são de responsabilidade exclusiva de seus autores.

Impressa no Brasil / Printed in Brazil

Distribuída em todo Território Nacional 


\title{
Autonomia das Procuradorias dos Estados
}

\begin{abstract}
José Augusto Delgado
Ministro do STJ. Acadêmico da Academia Brasileira de Letras Jurídicas. Acadêmico da Academia Brasileira de Direito Tributário. Doutor Honoris Causa da Universidade Estadual do RN. Professor de Direito Público (Administrativo, Tributário e Processual Civil). Professor UFRN (aposentado). Ex-professor da Universidade Católica de Pernambuco. Sócio Honorário da Academia Brasileira de Direito Tributário. Sócio Benemérito do Instituto Nacional de Direito Público. Conselheiro Consultivo do Conselho Nacional das Instituições de Mediação e Arbitragem. Integrante do Grupo Brasileiro da Sociedade Internacional do Direito Penal Militar e Direito Humanitário. Professor convidado da UNICEUB, no Curso de Especialização em Direito Público.
\end{abstract}

Palavras-chave: Procuradorias dos Estados. Poder Judiciário. Advocacia Pública.

Sumário: 1 Introdução - 2 A atuação relevante das Procuradorias dos Estados acena para a sua autonomia. Apoios a essa pretensão - 3 Autonomia e responsabilidades. Código de Ética - 4 Conclusões

\section{Introdução}

As questões jurídicas que envolvem as discussões instauradas em torno da pretensão das Procuradorias estaduais serem consideradas autônomas, no exercício das suas atividades administrativas e judiciais, têm sido motivo de preocupação da Ciência Jurídica contemporânea, haja vista buscar assentar postulados e princípios que concorram para a consolidação desse panorama no ordenamento jurídico brasileiro.

A doutrina jurídica, de há muito, tem entendido que os procuradores dos Estados exercem atribuições cercadas de prerrogativas constitucionais.

O referido modo de pensar tem a sua base na interpretação do art. 132 da Constituição Federal, a dizer:

"Os Procuradores dos Estados e do Distrito Federal, organizados em carreira, na qual o ingresso dependerá de concurso público de provas e títulos, com a participação da Ordem dos Advogados do Brasil em todas as suas fases, exercerão a representação judicial e a consultoria jurídica das respectivas unidades federativas" (Redação que foi dada pela Emenda Constitucional $n^{\circ} 19$, de 04 de junho de 1998, que modificou o regime e dispôs sobre princípios e normas da Administração Pública, servidores e agentes públicos, controle de despesas e finanças públicas e custeio de atividades a cargo do Distrito Federal, e deu outras providências).

A \& C R. de Dir. Administrativo e Constitucional, Belo Horizonte, ano 7, n. 27, p. 43-59, jan./mar. 2007 
O referido dispositivo constitucional está inserido na Seção II que trata da Advocacia Pública. Esta Seção II, por sua vez, integra o Capítulo IV que compreende as Funções Essenciais à Justiça, integrante do Capítulo III que cuida do Poder Judiciário.

A interpretação do mencionado regramento posto na Carta Maior não pode ser feita de modo a considerá-lo como não integrante do sistema determinado para o funcionamento do Poder Judiciário.

A organização das Procuradorias dos Estados foi colocada ao lado, em posição de horizontalidade, do Ministério Público (Seção I) e da Advocacia e da Defensoria Pública (Seção III).

As atribuições dos Procuradores dos Estados são, conseqüentemente, por vontade constitucional, consideradas como funções essenciais ao funcionamento da Justiça, o que lhes elevam a nobreza maior de instituição permanente e independente, com função específica de representação judicial das unidades federativas do Brasil, bem como de consultoria jurídica, o que os transforma, por defenderem os Estados, em advogados da cidadania, por somente com esta assumirem o compromisso de bem servir no campo que a Constituição lhes reservou.

Aos Procuradores dos Estados, por outro ângulo, são aplicáveis os princípios constitucionais da sua indispensabilidade na defesa judicial dos entes federados, pelo que estão protegidos pela imunidade atribuída aos advogados. São mensageiros e, ao mesmo tempo, soldados defensores das liberdades públicas e do patrimônio estatal. Lutam pelas garantias instituídas pela ordem jurídica, pautando as suas ações na valorização da dignidade humana e no fortalecimento da cidadania.

Por outro lado, uma análise das manifestações já tornadas públicas pelo Supremo Tribunal Federal, em julgamentos emitidos sobre o posicionamento dos Procuradores do Estado no contexto jurídico, permite que se apresente, em forma de enunciados, o quadro seguinte:

a) $\mathrm{O}$ art. 132 da Constituição Federal operou uma inderrogável imputação específica e exclusiva atividade funcional aos membros integrantes da Advocacia Pública do Estado, cujo processo de investidura nos cargos a serem exercidos depende de prévia aprovação em concurso público de provas e títulos, conforme assinalado na ADIN no 881-1, Rel. Min. Celso de Mello, Informativo do STF n. 68.

b) Não pode a Constituição Estadual prever a impossibilidade de inamovibilidade dos Procuradores, em face da relevância de suas 
funções (ADIN n. 1.246/PR, Rel. Min. Moreira Alves, Informativo n. 8).

c) "O princípio da razoabilidade, a direcionar no sentido da presunção do que normalmente ocorre, afasta a exigência, como ônus processual, da prova da qualidade de Procuradores do Estado por quem assim se apresente e subscreve ato processual. O mandato é legal e decorre do disposto nos artigos 12 e 132, respectivamente, do Código de Processo Civil e da Constituição Federal" (STF - 2a Turma, RE n. 192.533-1 (São Paulo), Rel. Min. Marco Aurélio).

d) O Supremo Tribunal Federal reconhece constitucional dispositivo legal que cria Procuradoria-Geral das Assembléias Legislativas, com funções destacadas das atribuídas à ProcuradoriaGeral do Estado (ADIN 175, RTJ, 154/14).

e) $\mathrm{O}$ Poder autônomo (mesmo não personalizado) poder criar assessoria jurídica própria (ADIN 825, julgada em 22.04.1993). ${ }^{1}$

f) "A representação judicial do Estado, por seus procuradores, deriva da lei, dispensada a juntada de mandato, diferentemente das autarquias e sociedades de economia mista, cujos advogados deverão juntar procuração" (STF, RDA, 179/158).

g) "Não ofende a Constituição Federal dispositivos de Cartas Estaduais que conferem aos Procuradores do Estado prerrogativas de foro, atribuindo ao Tribunal de Justiça a competência para processá-los e julgá-los nos crimes comuns e de responsabilidade, observada a regra do art. $\left.125, \S 1^{\circ}\right){ }^{2}$

O quadro formado pelas idéias doutrinárias e jurisprudenciais anteriormente destacadas nos leva a configurar uma sistemática presente na Constituição Federal que aponta, de modo incontrovertido, para a configuração autônoma das Procuradorias Judiciais dos Estados na organização da estrutura estatal.

\footnotetext{
As citações jurisprudenciais citadas foram extraídas da obra Constituição Federal interpretada, da autoria de Alexandre de Moraes, Ed. Atlas, 2002.

2 CF, Art. 125: "Os Estados organizarão sua Justiça, observados os princípios estabelecidos nesta Constituição". Parágrafo $1^{\circ}$ A competência dos tribunais será definida na Constituição dos Estados, sendo a lei de organização judiciária de iniciativa do Tribunal de Justiça".
}

A \& C R. de Dir. Administrativo e Constitucional, Belo Horizonte, ano 7, n. 27, p. 43-59, jan./mar. 2007 


\section{A atuação relevante das Procuradorias dos Estados acena para a sua autonomia. Apoios a essa pretensão}

Consagrado está, segundo o nosso entendimento, em face da integração das Procuradorias dos Estados no Capítulo III da Constituição e do seu reconhecimento de ser atividade essencial à atividade Judiciária, o propósito do legislador constituinte de considerá-las como instituições independentes, autônomas, com princípios próprios que regem os seus destinos.

Os Procuradores, no campo de suas atribuições definidas na Carta Magna, possuem prerrogativas constitucionais explícitas e implícitas, todas vinculadas aos postulados da legalidade, da moralidade, da impessoalidade, da publicidade, da eficiência, da razoabilidade, da proporcionalidade, da precaução e da ponderação, fortes esteios do regime Democrático.

A vinculação de suas funções a estes princípios gera, conseqüentemente, a caracterização da necessidade de seus órgãos serem autônomos na organização estatal, nivelando-se ao Ministério Público e aos Defensores Públicos.

Essas prerrogativas constitucionais implícitas foram estudadas, com profundidade, por Marco Túlio de Carvalho Rocha, Procurador do Estado de Minas Gerais, em trabalho intitulado "A Unicidade Orgânica da Representação Judicial e da Consultoria Jurídica do Estado de Minas Gerais", publicado na Revista de Direito Administrativo, Rio de Janeiro, n. 223, p. 169-197, jan./mar. 2001. O que escreveu o mencionado autor, pela excelência do conteúdo, determina que seja feita uma apresentação, embora resumida, do pensamento exposto.

Em síntese, podemos concluir que, conforme anunciado por Marco Túlio de Carvalho Rocha, são prerrogativas constitucionais implícitas dos Procuradores dos Estados as seguintes:

a) a função de controle da legalidade dos atos da Administração Pública;

b) a independência funcional.

Portanto, ao lado das prerrogativas explícitas que são as de representar judicialmente o Estado e prestar-lhe consultoria, estão as implícitas que contribuem para o fortalecimento da instituição.

Por outro ângulo, há de ser cultuado o pregado por Diogo de Figueiredo Moreira Neto, no artigo "As funções essenciais à justiça e as procuraturas constitucionais", publicado na Revista da Procuradoria Geral

A \& C R. de Dir. Administrativo e Constitucional, Belo Horizonte, ano 7, n. 27, p. 43-59, jan./mar. 2007 
do Estado de São Paulo, p. 25 et seq., dez. 1991, onde estão proclamados os princípios constitucionais informativos das Procuradorias dos Estados: essencialidade, institucionalidade, igualdade, unidade, organicidade unipessoal, independência funcional, inviolabilidade de autonomia administrativa e autonomia de impulso.

Segundo Diogo de Figueiredo Moreira Neto, no artigo citado, esses princípios informam que:

"A essencialidade está afirmada na própria designação constitucional das funções. Elas não podem deixar de existir, com as características e roupagem orgânica que lhes são próprias, e nem tolhidas ou prejudicadas no seu exercício. Sua essencialidade, em última análise, diz respeito à manutenção do próprio Estado Democrático de Direito e à construção do Estado de Justiça.

A institucionalidade também resulta evidente da própria criação constitucional; explícita, no caso do Ministério Público (art. 127), da Advocacia Geral da União (art. 131) e da Defensoria Pública, e implícita, quanto aos Procuradores de Estado e do Distrito Federal (art. 132).

A igualdade decorre da inexistência de hierarquia entre os interesses cometidos a cada uma das funções essenciais à Justiça; a igual importância das funções determina a igualdade constitucional das procuraturas que as desempenham.

A unidade, que consiste na inadmissibilidade de existirem instituições concorrentes, com a mesma base política e com chefias distintas, para o exercício das funções cometidas a cada procuratura, está explícita no art. $127, \S 1^{\circ}$, ao tratar do Ministério Público, e no art. $127, \S 1^{\circ}$, quando faz menção à Advocacia Geral da União; implícita, para os Procuradores de Estado e do Distrito Federal e para a Defensoria Pública, conforme revelação dos arts. 132 a 134 .

A organicidade unipessoal decorre da fundamental e genérica condição de advogado, estabelecida no artigo 133 da Constituição. Cada agente das procuraturas constitucionais é um órgão individual, para empregar nomenclatura de Marcello Caetano, com sua natureza institucional. Isso está explícito para os Procuradores dos Estados e Distrito Federal (art. 132), mas fica implícito para os demais membros das procuraturas constitucionais.

A independência funcional diz respeito à insujeição das procuraturas constitucionais a qualquer outro Poder do Estado em tudo o que tange ao exercício das funções essenciais à justiça.

A inviolabilidade é um consectário da independência funcional no

A \& C R. de Dir. Administrativo e Constitucional, Belo Horizonte, ano 7, n. 27, p. 43-59, jan./mar. 2007 
que respeita às pessoas dos agentes públicos das procuraturas constitucionais. Assim como nenhum dos Poderes pode interferir no desempenho das funções essenciais à justiça, nenhum deles pode constranger, por qualquer modo, até mesmo pela manipulação de remuneração ou de qualquer outro direito, o agente nelas investido. O princípio ficou explícito genericamente, no artigo 135 da CF, para todas as funções essenciais à justiça, mas há garantias específicas de vitaliciedade e de inamovibilidade que privilegiam os membros do Ministério Público e da Defensoria Pública. Ainda assim, a mobilidade dos membros da Advocacia Geral da União e das Procuradorias dos Estados e do Distrito Federal não poderá ser arbitrária, mas, ao contrário, sempre com motivação transparente, para que não encubra os mascarados atentados à independência funcional e à inviolabilidade de seus agentes.

A autonomia administrativa consiste na outorga, às procuraturas constitucionais, da gestão daqueles meios administrativos necessários para garantir-se-lhes a independência para atuar, mesmo contra os interesses de qualquer dos Poderes, notadamente do Poder Executivo, de cuja estrutura administrativa se vale. Trata-se, portanto, de uma condição constitucional para que prevaleçam, na prática, todos os demais princípios, tal como a Carta Política de 1988 veio a reconhecer também como imprescindível a expandir a auto-administração do Poder Judiciário (art. 96, I, II e III, e 99). Da mesma forma, para o Ministério Público, o alcance dessa autonomia está definido explicitamente no artigo 127, §2 , deixando-se implícito, o princípio, no tocante às demais procuraturas, para ser considerado nas respectivas Constituições e leis orgânicas, conforme o caso.

A autonomia de impulso, por fim, é o princípio fundamental da atuação das procuraturas constitucionais. Ele preside e orienta o poderdever desses órgãos de tomar todas as iniciativas que lhes são abertas pela Constituição Federal, pelas Constituições Estaduais e pelas leis, para o velamento e a defesa dos interesses que lhes forem confiados. Em termos gerais, cabe-lhes zelar pela juridicidade, desenvolvendo seu controle institucional de provedoria através de atividades consultivas, de fiscalização, esta de ofício, e de atividades postulatórias, tudo conforme os âmbitos de competência funcional e territorial próprios a cada uma delas."

Após descrever as características dos princípios anteriormente anunciados, Diogo de Figueiredo Moreira Neto prega que o único limite imposto à atuação dos Procuradores dos Estados é a própria ordem jurídica.

A \& C R. de Dir. Administrativo e Constitucional, Belo Horizonte, ano 7, n. 27, p. 43-59, jan./mar. 2007 
Cabe-lhes defender a ordem jurídica tendo como balizas as regras, os princípios e os postulados dessa própria ordem jurídica.

No contexto das considerações que estão sendo desenvolvidas no sentido da defesa da autonomia institucional das Procuradorias dos Estados, não podemos deixar de registrar a lição de José Afonso da Silva, ao interpretar o art. 132 da Constituição Federal, em sua obra Comentário contextual à Constituição. 2. ed. São Paulo: Malheiros, 2006:

"A carreira de procurador do Estado e do Distrito Federal foi institucionalizada em nível de Constituição Federal. Isso significa a institucionalização dos órgãos estaduais de representação e de consultoria dos Estados, uma vez que os procuradores, a que se incumbe essa função no art. 132 da Carta Magna, hão de ser organizados em carreira dentro de uma estrutura administrativa unitária em que sejam todos congregados."

Na linha do que estamos defendendo, merece somar o entendimento de Bernardo Cabral exposto no parecer que apresentou a respeito da Reforma do Poder Judiciário, quando relator da mesma. Disse o ilustre senador de então e jurista de ontem e de hoje:

"Estou convencido de que o atrelamento orçamentário das Procuradorias ao Executivo, quase que às raias da dependência e da subserviência, transformam os advogados do Estado em advogados do detentor do poder no Estado, e não é essa a inspiração da razão de ser e de atuar das Procuradorias. A autonomia financeira é a alforria das Procuradorias, que poderão dedicar-se à defesa administrativa e judicial da coisa pública, desvinculados das vontades e imposições do eventual detentor da chefia do Executivo, zelando pelo respeito à Constituição e às leis, e não viabilizando, com verniz jurídico, as determinações do detentor do mandato popular. É sempre bom lembrar que o bem público é indisponível, e assim também o é a sua defesa."

Embora a manifestação acima não tenha feito qualquer referência à autonomia administrativa e funcional, há de ser considerada como um avanço a reconhecer a necessidade da autonomia financeira.

Gustavo Calmon Holliday, Procurador do Estado do Espírito Santo, em artigo intitulado "A importância das Procuradorias e sua função", disponibilizado via internet, site: < http://www.apes.org.br>, pronunciou-se sobre o assunto, fazendo as afirmações que passam a ser transcritas:

"De certa forma, os Procuradores de Estado são advogados de todos os cidadãos, uma vez que têm como objetivo-fim A DEFESA DO PATRI-

A \& C R. de Dir. Administrativo e Constitucional, Belo Horizonte, ano 7, n. 27, p. 43-59, jan./mar. 2007 


\section{MÔNIO PÚBLICO.}

Nesse sentido concluiu José Roberto de Morais, no artigo 'As prerrogativas e o interesse da Fazenda Pública': No momento em que a Fazenda pública é condenada, sofre um revés, contesta uma ação ou recorre de uma decisão, o que se estará protegendo, em última análise, é o erário. É exatamente essa massa de recurso que foi arrecadada e que evidentemente supera, ai sim, o interesse particular. Na realidade, a autoridade pública é mera administradora.

Diante de tal premissa, ou seja, de que os procuradores defendem o patrimônio da coletividade, inclusive promovendo a cobrança dos créditos da Fazenda Pública, não se pode conceber que o 'Escritório de Advocacia dos cidadãos' tenha um contingente insuficiente e que os seus profissionais sejam mal-remunerados, pois, inevitavelmente, o prejuízo será do próprio erário que arcará com as conseqüências deletérias de tal situação.

É óbvio que, com um número insuficiente de procuradores, a qualidade técnica do trabalho desenvolvido é comprometida, refletindo-se diretamente na reputação pessoal desses profissionais, cujo trabalho não pode ser realizado com a dedicação devida e tampouco poderão desculpar-se futuramente sob a alegação de excesso de serviço.

É preciso adotar mecanismos, em nível constitucional, que impossibilitem aos administradores desvirtuar as finalidades dos órgãos públicos.

Conforme ensinamento de Hely Lopes Meirelles, 'toda atividade do administrador público deve ser orientada para o bem comum da coletividade. Se dele o administrador se afasta ou desvia, trai o mandato de que está investido, porque a comunidade não institui a Administração senão como meio de atingir o bem-estar social. Ilícito e imoral será todo ato administrativo que não for praticado no interesse da coletividade'.

Todavia, e lamentavelmente, na prática a realidade é muito diferente. Na maior parte desses Órgãos, o quadro é deficiente, a remuneração é baixa e a estrutura é inadequada. Possivelmente esse quadro pode ser explicado pela inexperiência administrativa. A QUEM PODERIA INTERESSAR UMA ASSESSORIA JURÍDICA DEFICIENTE?

Mesmo orgulhosos por desempenharem atividade de especial relevância, a baixa remuneração, a deficiência estrutural e o alto volume de processos a que os procuradores de todas as Unidades Federadas estão submetidos, tem acarretado a evasão para outros cargos menos atribulados.

Tradicionalmente, os Procuradores de Estado são profissionais respeitados no meio jurídico e, inafastavelmente, devem ser aprova- 
dos em concursos públicos de provas e títulos altamente concorridos. Juristas de expressão nacional como Sérgio Ferraz, Carlos Ary Sundfeld, Michel Temer, Maria Sylvia Di Pietro, Carmem Lúcia Antunes Rocha, Luís Roberto Barroso são Procuradores de Estado.”

A seguir, conclui pela pregação da autonomia administrativa, financeira e funcional como a via necessária para a instituição alcançar o fortalecimento que necessita.

Afirma:

“5. A AUTONOMIA COMO SOLUÇÃO

Para se evitar os desvios de finalidade e o conseqüente enfraquecimento das instituições, é preciso promover as modificações necessárias nas Constituições, de maneira que o administrador fique impossibilitado de alterar toda uma estrutura para atender interesses menores.

Conforme ressaltou Seabra Fagundes, 'O que importa principalmente em uma Constituição não é se resuma ela em texto breve. O que se deve aspirar é que ela atenda, no seu bojo, às várias relações ou situações que, segundo as condições político-sociais do país, mereçam ser disciplinadas com exatidão e de modo a perdurarem no tempo, para que os poderes do Estado não as possam desconhecer, ferir ou deturpar'.

Em 1998, por meio da Emenda n $19 / 98$, a Constituição Federal teve o título da Seção II, do Capítulo IV, do Título IV, alterado para ADVOCACIA PÚBLICA, em substituição a Advocacia-Geral da União, elevando-se as Procuradorias ao status constitucional.

Maurício Antonio Ribeiro Lopes, na obra Comentários à reforma administrativa, Editora RT, escreveu: 'A Emenda Constitucional no 19/98 determinou a correção da rubrica relativa a Seção II do Capítulo IV do Título IV da Constituição Federal, substituindo a expressão Advocacia-Geral da União por Advocacia Pública. Tal modificação elegeu definitivamente as Procuradorias Gerais dos Estados, inclusive, em órgãos de nível constitucional, no que procedeu com acerto em vista do papel de especial relevância que desempenham aqueles profissionais'.

Dando continuidade à necessidade de evolução e aprimoramento das relações jurídicas e das instituições, está tramitando no Congresso Nacional uma nova PEC, Proposta de Emenda Constitucional que dá às Procuradorias dos Estados e do Distrito Federal autonomia funcional e administrativa.

Essa proposta inclui o $\S 2^{\circ}$ no art. 132 da CF, que está redigido da seguinte forma: Às Procuradorias Estaduais e do Distrito Federal são asseguradas autonomia funcional e administrativa, e a iniciativa de sua proposta orçamentária

A \& C R. de Dir. Administrativo e Constitucional, Belo Horizonte, ano 7, n. 27, p. 43-59, jan./mar. 2007 
dentro dos limites estabelecidos na lei de diretrizes orçamentárias e subordinação ao disposto no art. $99 . \$ 2^{\circ}$.

Trata-se de um avanço sem precedentes. Finalmente, as Procuradorias passariam a gerir seus próprios recursos, podendo realizar, por conta própria, os concursos públicos para preenchimento das vagas existentes e aparelhar os órgãos.

Somente com a almejada independência as Procuradorias ficariam livres das vicissitudes ideológicas dos administradores que se sucedem de quatro em quatro anos, podendo, enfim, reestruturar esses Órgãos de forma a cumprirem plenamente sua atribuição constitucional que é, em última análise, a preservação do interesse e do patrimônio público.”

Há, entre tantos outros documentos defendendo a autonomia financeira, funcional e administrativas das Procuradorias, o posicionamento exposto nesse sentido pela Associação Nacional dos Procuradores do Estado (ANAPE), em ofício dirigido ao Congresso Nacional, por ocasião da Reforma do Poder Judiciário, onde estão expressadas as mais convincentes razões para o acolhimento dessa pretensão.

Eis o seu conteúdo:

"O texto constitucional vigente, promulgado em 1988, organizou as carreiras Jurídicas estatais e, marcadamente, definiu o papel do Ministério Público, da Advocacia Pública e da Defensoria Pública - arts. 127 a 130, 131 a 132 e 133.

A Constituição Federal, ao definir essas instituições como funções essenciais à Justiça, atribuiu ao Ministério Público a defesa da ordem Jurídica, do regime democrático e dos interesses sociais e individuais indisponíveis; à Advocacia Pública - exercida no nível federal pela Advocacia da União e, no plano estadual, pelas Procuradorias dos Estados e do Distrito Federal —, a representação Judicial e a consultoria Jurídica das respectivas unidades federadas; e a Defensoria Pública a defesa dos menos favorecidos, ou seja, pobres na forma da lei.

Os órgãos da Advocacia Pública tiveram reforçado, desse modo, a sua missão Institucional tradicional de representar os entes federativos, garantindo sempre a legalidade da sua atuação administrativa. Nessa perspectiva, a função constitucional das Procuradorias dos Estados e do Distrito Federal engloba a defesa do patrimônio público, inclusive contra os eventuais abusos de poder promovidos pelos governantes, no exercício do seu mandato.

A \& C R. de Dir. Administrativo e Constitucional, Belo Horizonte, ano 7, n. 27, p. 43-59, jan./mar. 2007 
Também ao exercer a representação judicial da unidade federada, cumpre ao Procurador de Estado responder isentamente às ações propostas contra a Fazenda Pública e promover, quando necessário, as medidas judiciais cabíveis para a defesa do interesse do ente federativo, não na perspectiva dos detentores do poder, mas na salvaguarda do interesse e do patrimônio públicos.

Nessa perspectiva, a autonomia das Procuradorias dos Estados e do Distrito Federal é fator preponderante para que se garanta uma representação Judicial pautada pela técnica e respeito à lei.

Também no exercício de sua função consultiva, as Procuradorias dos Estados e do Distrito Federal funcionam como órgão de balizamento e orientação jurídica para todos os órgãos da Administração Pública, constitucionalmente vinculada aos princípios da legalidade, moralidade, impessoalidade, publicidade e eficiência.

Sendo, pois, a primeira instância de controle de legalidade dos atos da Administração Pública, as Procuradorias dos Estados e do Distrito Federal atuam de forma preventiva, realizando o controle interno da legalidade das práticas administrativas, promovendo um exame prévio da legitimidade dos atos a serem praticados, conferindo-lhes a necessária legitimidade e coibindo as práticas perniciosas.

Mesmo com a existência desse controle, que não exclui aqueles exercidos pelo Judiciário, Ministério Público e Tribunal de Contas, constatam-se ainda assim abusos por parte dos detentores do poder, com graves e sérios prejuízos à coletividade, com repercussão no erário. Daí a necessidade do aprimoramento da atuação das Procuradorias dos Estados e do Distrito Federal, condicionada à autonomia perseguida na denominada Reforma do Poder Judiciário.

A inserção das Procuradorias dos Estados e do Distrito Federal no texto constitucional foi festejada pelos mais ilustres juristas pátrios, como Diogo de Figueiredo Moreira Neto, José Afonso da Silva, Celso Antônio Bandeira de Mello, dentre outros.

Dentro desse contexto, a autonomia funcional, administrativa e financeira das Procuradorias dos Estados e do Distrito Federal representa fator indispensável para que a sua função institucional seja alcançada e preservada de eventuais interferências políticas promovidas pelos titulares do poder, no exercício dos seus mandatos.

O caráter fundamental dessa atuação das Procuradorias dos Estados

A \& C R. de Dir. Administrativo e Constitucional, Belo Horizonte, ano 7, n. 27, p. 43-59, jan./mar. 2007 
e do Distrito Federal não exclui nem minimiza a presença e efetividade da atuação do Ministério Público que, enquanto fiscal da aplicação da lei, certamente não detém essa prerrogativa de maneira exclusiva, tornando-se mais complexo e efetivo o controle de legalidade quando, paralelamente exercido pelos órgãos da Advocacia Pública, que detêm igualmente essa função institucional.

O bom desempenho das funções constitucionais pelo Ministério Público — hoje senso comum — não afasta a atuação das Procuradorias dos Estados e do Distrito Federal, igualmente comprometidas com o controle da legalidade dos atos administrativos, que necessitam, para exercer de forma eficaz o seu múnus público, da necessária autonomia administrativa, funcional e financeira.

A experiência histórica demonstra que, apenas a partir de sua efetiva independência orçamentária e financeira, tornou-se possível ao Poder Judiciário e ao próprio Ministério Público exercerem, com efetividade, a sua função constitucional.

Em busca desse desiderato, o Congresso Nacional tem buscado aperfeiçoar as carreiras essenciais à justiça. Tome-se, por exemplo, o tratamento isonômico concedido quanto ao subteto previsto na Emenda Constitucional $n^{\circ} 41 / 2004$, que distingue as carreiras essências à justiça das demais carreiras de Estado.

Outro, é o tratamento isonômico previsto na Emenda Constitucional $n^{\circ} 68 / 2003$, que trata da idade mínima para exercício das carreiras previstas nas funções essenciais à justiça.

Por essa mesma razão, não pode prevalecer o entendimento de se retirar à autonomia conquistada pelas Procuradorias Gerais dos Estados e do Distrito Federal no texto original da denominada Reforma do Poder Judiciário, resultante de um acordo de liderança na Câmara, visando tão-somente ao aprimoramento da administração pública, que configuraria um inadmissível retrocesso ao bom desempenho da função institucional da Advocacia Pública, consoante advertiu o eminente Senador Bernardo Cabral, Relator do Projeto de Emenda Constitucional, quando de sua apreciação:

"Estou convencido de que o atrelamento orçamentário das Procuradorias ao Executivo, quase que às raias da dependência e da subserviência, transformam os advogados do Estado em advogados do detentor do poder no Estado, e não é essa a inspiração da razão de ser e de atuar das Procuradorias. A autonomia financeira a alforria das 
Procuradorias, que poderão dedicar-se à defesa administrativa e judicial da coisa pública, desvinculados das vontades e imposições do eventual detentor da chefia do Executivo, zelando pelo respeito à Constituição e às leis, e não viabilizando, com verniz jurídico, as determinações do detentor do mandato popular. É sempre bom lembrar que o bem público é indisponível, e assim também o é a sua defesa.

Em razão disso, é de todo improcedente pensar que atingiremos a maturidade institucional com instituições fracas e dependentes, subalternas aos mínimos interesses que não sejam aqueles previstos na Carta Magna.

Com o fortalecimento das Procuradorias Gerais dos Estados e do Distrito Federal, não se pretende enfraquecer nem retirar do governante qualquer de seus poderes ou prerrogativas, almeja-se buscar um maior equilíbrio entre os ideais políticos e a legalidade, por vez tão esquecida.

As Procuradorias Estaduais e a do Distrito Federal já possuem as autonomias administrativa e funcional em suas Leis Orgânicas, e algumas também possuem a financeira (RJ, DF, MS, RN). Entretanto, esse dispositivo sendo elevado à categoria constitucional, sedimentaria, definitivamente, inclusive na doutrina e jurisprudência, a condição de agentes políticos que detêm os Procuradores de Estado e do Distrito Federal. Ademais, é típico dos regimes democráticos o fortalecimento das instituições que prestam atividades de Estado, sendo um contrasenso tal posição.

O medo ou receio dos governadores improcede por completo. A autonomia financeira - já que as outras duas existem infraconstitucionalmente - não vem acompanhada da temida independência somente concedida ao órgão Ministério Público —, despregando as Procuradorias Gerais dos Estado e do Distrito Federal do Poder Executivo, muito menos contempla o poder de iniciativa legislativa para fixar seus próprios subsídios ou criar cargos, por exemplo.

A chamada autonomia financeira nada mais é do que a iniciativa de sua proposta orçamentária dentro dos limites estabelecidos na lei, sujeito ao crivo do Legislativo e do Executivo, além do repasse a cada dia 20 do mês, em duodécimos, dos recursos correspondentes às dotações orçamentárias. Isto quer dizer que as Procuradorias Estaduais e do Distrito Federal deixarão apenas de mendigar recursos para manter-se, sem ter, por exemplo, seus telefones cortados, xerox quebrada, ausência absoluta de material de expedIente, como acontece em alguns Estados da federação.

O Ministério Público é o defensor da sociedade, a Defensoria A \& C R. de Dir. Administrativo e Constitucional, Belo Horizonte, ano 7, n. 27, p. 43-59, jan./mar. 2007 
Pública dos pobres, na forma da lei, e as Procuradorias Gerais dos Estados e do Distrito Federal defendem os Estados e o DF, além de integrarem o Capítulo IV. Das Funções Essenciais à Justiça. Portanto, indaga-se: Qual o motivo do tratamento diferenciado dentre as funções essenciais à justiça? Por que somente os procuradores dos Estados e do Distrito Federal não podem ter autonomia?

A Câmara dos Deputados teve essa sensibilidade, que pareceu faltou a CCJ do Senado, mas que, certamente, não será compactuada pelo Plenário, uma vez que a atividade do Procurador de Estado e do Distrito Federal é relevante ao estado e ao governo, além de ser um instrumento de fortalecimento para o Estado Democrático de Direito, em razão do controle Interno da legalidade e moralidade administratIva que exerce.

Com essas considerações, a Associação Nacional dos Procuradores de Estado (ANAPE) espera contar com o apoio de Vossa Excelência para que seja mantida a autonomia das Procuradorias Geral dos Estados e do Distrito Federal ( $\$ 2^{\circ}$ do art. 132 e art. 168 do texto da PEC ${ }^{\circ}$ 29/00), aprovada pela Câmara Federal, por proposta do PMDB, para continuarmos lutando em busca de um Brasil mais justo, democrático e fraterno.

Brasília, 13 de maio de 2004. - Omar Coelho de Mello, Presidente”

Como sabido, a reivindicação acima não foi inserida na $\mathrm{EC} \mathrm{n}^{\circ} 45$, permanecendo a autonomia financeira, funcional e administrativa nas configurações até então existentes, isto é, deficitária em relação aos anseios da cidadania.

$\mathrm{O}$ fato da $\mathrm{EC} \mathrm{n}^{\circ} 45$ não haver acolhido a autonomia financeira, funcional e administrativa das Procuradorias dos Estados não serve de motivo para que a pregação das idéias nesse sentido sejam esmorecidas. Pelo contrário. Fortalecidos devem ser os movimentos em prol da autonomia, com instalação de seminários sobre o assunto, publicações de trabalhos doutrinários e investigações científicas a bem demonstrar que o fortalecimento das Procuradorias dos Estados reverte em uma garantia para tornar cada vez mais rígida a estrutura do Estado Democrático de Direito.

\section{Autonomia e responsabilidades. Código de Ética}

É evidente que, atualmente, os membros das Procuradorias dos Estados, embora não garantidos pela autonomia constitucional financeira, administrativa e funcional, desempenham as suas atribuições com compromissos selados aos princípios da legalidade, da moralidade, da impessoa- 
lidade, da publicidade, do respeito à dignidade humana e à valorização da cidadania.

O movimento pela autonomia deve caminhar, contudo, para o seu fortalecimento, aliado a posicionamentos que cada vez mais determinem a obrigatoriedade de cumprimento dos princípios axiológicos, em sua extensão maior, pelos procuradores.

Entendemos de máxima eficácia, para o momento contemporâneo, a defesa por todas as Procuradorias dos Estados e do Distrito Federal, com apoio da Associação Nacional e das Associações locais, de um projeto de lei que estabeleça um Código de Ética exclusivamente para a atuação dos Procuradores, a exemplo do que existe para os advogados e para a magistratura (Lei Orgânica da Magistratura).

Este Código de Ética, devidamente institucionalizado pela transparência da lei, definindo atribuições a Conselhos para fiscalizar as suas determinações, contribuiria para fortalecer a instituição em toda a sua plenitude e marcará a diferenciação em sua natureza como entidade necessária, autônoma, às funções administrativas da Justiça.

O mencionado Código de Ética dos Procuradores dos Estados conviveria, de modo harmônico, com o Código de Ética dos Advogados, sendo aplicado às situações explícitas por ele previstas.

A sua base de constituição, segundo nosso entendimento, deve considerar, entre outros, os aspectos seguintes:

a) regras deontológicas fundamentais especialmente voltadas para a atuação dos Procuradores;

b) disposições destinadas ao envolvimento dos Procuradores com o Estado e a fixação de limites para esses relacionamentos;

c) disciplinação do sigilo profissional dos Procuradores e da sua compatibilidade com o interesse público;

d) $\quad \mathrm{d}$ e t e r m i n a ç õ e s $\quad$ s o b r e a publicidade dos atos inerentes às atividades judiciais e de consultoria;

e) estabelecimentos de deveres de urbanidade;

f) composição do tribunal de ética e disciplinar;

g) procedimentos a serem adotados para apurar infrações éticas;

h) ditames que consagrem a preservação de uma conduta honrosa, nobre e digna, zelando pelo seu caráter de essencialidade, indis-

A \& C R. de Dir. Administrativo e Constitucional, Belo Horizonte, ano 7, n. 27, p. 43-59, jan./mar. 2007 
pensabilidade e voltada para proteção do interesse público.;

i) incentivos para uma atuação com destemor, independência, honestidade, lealdade, dignidade, veracidade e boa-fé;

j) idem de atitudes voltadas para o aperfeiçoamento pessoal e profissional, contribuindo, permanentemente, para o aperfeiçoamento da Ciência Jurídica.;

k) outras disposições concernentes aos objetivos de um Código de Ética.

\section{Conclusões}

Pregamos, como acima demonstrado, a autonomia financeira, administrativa e funcional das Procuradorias dos Estados, porque, nos meus 41 anos de exercício de magistratura, completados em 27 de abril de 2005, somos testemunha ocular, presente, diuturna, da seriedade, do esforço, da dignidade, da entrega profissional sem outros compromissos senão o de ver o direito ser bem aplicado, com que os Procuradores dos Estados exercem as suas atribuições.

Não fazemos distinções. Os Procuradores do Norte, os Procuradores do Sul, os Procuradores do Nordeste, os Procuradores do Sudoeste, os Procuradores de todas as Regiões deste nosso Brasil, na defesa dos direitos da cidadania e da dignidade humana, que são os direitos do Estado, têm desenvolvido com as convicções jurídicas que constroem e com o esforço desmedido que empregam as atribuições que lhe são confiadas pelo Estado, em nome do povo.

Somos testemunhas presentes, repetimos, de que os Procuradores dos Estados, na concepção que possuem de que não são empregados dos Chefes dos Poderes, porém, súditos diretamente vinculados aos anseios da cidadania, cumprem, de acordo com os comandos constitucionais, especialmente, os dogmas da moralidade, as atividades inerentes à defesa do direito posto em Juízo.

Observamos exteriorizar em todos as suas ações, o compromisso que assumiram e que cumprem de lutar pela Justiça em nome do cidadão; de defenderem o Estado quando violado o direito que lhe é assegurado, pois, assim fazendo estão defendendo o patrimônio do povo. Demonstram sentir, com intensidade, a necessidade de imposição de segurança jurídica. Crêem no presente com o pensamento voltado para a construção de um futuro melhor para o Brasil, onde a dignidade impere em todos os rela- 
cionamentos, quer públicos e privados.

No dia a dia de nossas atividades de julgador, sentimos os Procuradores dos Estados transmitirem, a todos os instantes, valores que se aproximam do pensado por Noberto Bobbio, quando afirmou que "Com relação às grandes aspirações dos homens de boa vontade, já estamos demasiadamente atrasados. Busquemos não aumentar esse atraso com nossa incredulidade, com nossa indolência, com nosso ceticismo. Não tempos muito tempo a perder" (Noberto Bobbio, em sua obra $A$ era dos direitos. Tradução de Carlos Nelson Coutinho. Ed. Campus, p. 69).

Realmente, não temos tempo a perder. Os Procuradores dos Estados do Brasil, por terem essa conscientização, unem-se aos propósitos do Poder Judiciário, dos advogados, de todos os operadores do direito, para valorizarem os anseios dos estamentos sociais que compõem a Nação, tudo com o objetivo de dias melhores serem construídos no amanhã, com o fortalecimento da entrega da prestação jurisdicional voltada para o homem injustiçado, com o respeito ao postulado da moralidade, com a lei sendo interpretada e aplicada em prol da igualdade, da fraternidade, da consecução das esperanças, do fortalecimento das instituições, do encontro da extirpação das desigualdades sociais, da guarda da segurança pública, do engrandecimento dos valores dos núcleos familiares e educacionais, enfim, do modo como todos nós sonhamos e queremos como seja a Nação brasileira: retrato fiel de um Estado Democrático de Direito onde todos os postulados que o sustentam sejam obedecidos.

Informação bibliográfica deste texto, conforme a NBR 6023:2002 da Associação Brasileira de Normas Técnicas (ABNT):

DELGADO, José Augusto. Autonomia das Procuradorias dos Estados. A\&C Revista de Direito Administrativo e Constitucional, Belo Horizonte, ano 7, n. 27, p. 43-59, jan./mar. 2007.

A \& C R. de Dir. Administrativo e Constitucional, Belo Horizonte, ano 7, n. 27, p. 43-59, jan./mar. 2007 